\title{
REDESCRIPTION OF BLEEKERIA KALLOLEPIS (ACTINOPTERYGII: PERCIFORMES: AMMODYTIDAE) FROM CHENNAI, EASTERN INDIAN OCEAN
}

\author{
Kalli Valappil AKHILESH ${ }^{1}$, K.S.S.M. YOUSUF ${ }^{2}$, S.J. KIZHAKUDAN ${ }^{2}$, and P.U. ZACHARIA ${ }^{3}$ \\ ${ }^{1}$ ICAR-Central Marine Fisheries Research Institute, Mumbai Research Centre, Maharashtra, India \\ ${ }^{2}$ ICAR-Central Marine Fisheries Research Institute, Chennai Research Centre, Tamil Nadu, India \\ ${ }^{3}$ ICAR-Central Marine Fisheries Research Institute, Head Quarters, Kochi, Kerala, India
}

\begin{abstract}
Akhilesh K.V., Yousuf K.S.S.M., Kizhakudan S.J., Zacharia P.U. 2019. Redescription of Bleekeria kallolepis (Actinopterygii: Perciformes: Ammodytidae) from Chennai, eastern Indian Ocean. Acta Ichthyol. Piscat. 49 (1): 95-99.

Abstract. The yellow-striped sandlance, Bleekeria kallolepis Günther, 1862, is a poorly known ammodytid fish from the eastern Indian Ocean, known from fewer than five specimens. No detailed description or colour images of $B$. kallolepis have previously been available. We hereby provide a short taxonomic account of the species from its type locality Chennai, India with morphometrics and colour description.
\end{abstract}

Keywords: sandlance, Bleekeria kallolepis, Ammodytidae, Indian Ocean, Bay of Bengal, diversity

\section{INTRODUCTION}

The family Ammodytidae (Perciformes), known as sandlances or sand eels, comprises 7 genera and at least 31 species (Randall and Ida 2014, Fricke et al. 2018). They are small $(<30 \mathrm{~cm}$ TL) coastal fishes, with an elongate body and occur mostly in tropical or temperate waters. Some specialized fishes of the genera Ammodytes and Hyperoplus, however, occur in sub-boreal regions (Randall and Ida 2014). They form an important link in the marine ecosystem and food web where they are present (Harwood and Croxall 1988, Wanless et al. 1998, 2005).

Bleekeria Günther, 1862 is a genus native to the Indian and western Pacific Oceans. There are currently six recognized species in this genus: Bleekeria kallolepis Günther, 1862 from Chennai (India), eastern Indian Ocean; Bleekeria mitsukurii Jordan et Evermann, 1902 from Taiwan; Bleekeria viridianguilla (Fowler, 1931) from Hong Kong; Bleekeria murtii Joshi, Zacharia et Kanthan, 2012 from Tuticorin, Gulf of Mannar (India); Bleekeria estuaria Randall et Ida, 2014 from Pomene Estuary (Mozambique), and Bleekeria profunda Randall et Ida, 2014 from Saya de Malha Bank, southwestern Indian Ocean (Randall and Ida 2014, Fricke et al. 2018).

Bleekeria kallolepis Günther, 1862 was originally described based on material from Chennai, India (previously Madras). Since then, reports of the species have been rare (Day 1878, 1889, Pillay 1931, Krishnan and
Mishra 1993, Ida et al. 1994) possibly due to the limited commercial importance of this fish in the region or the lack of concentrated fish diversity studies in the Indian part of the Bay of Bengal. Since no detailed description with colour images of $B$. kallolepis has hitherto been available, we provide here a detailed taxonomic description of the species from its type locality, Chennai, India.

\section{MATERIALS AND METHODS}

Specimens of Bleekeria kallolepis were collected on 6 April 2018 during observations of fish landings at Chennai, on the south-east coast of India. The fish were captured by trawl boats that operate in shallow waters off Chennai in the western Bay of Bengal. The catch was dominated by $B$. kallolepis. The species were identified following Günther (1862), Day (1889), and Ida et al. (1994). Measurements of formalin-preserved specimens were taken following Randall and Ida (2014). Fin length was measured from base of first ray to the tip of last ray. The specimens are deposited in the fish collections of the ICAR-Central Marine Fisheries Research Institute (CMFRI), Mumbai, India.

Material examined. Four specimens: BNHS MF 16, 138.4 mm TL, collected at Chennai Fisheries harbour, Chennai, Tamil Nadu, India, 6 April 2018; BNHS MF 17, 140.1 mm TL, CMFRI M-BK-3, 139.6 mm TL, CMFRI M-BK4, $127.6 \mathrm{~mm}$ TL (Collection details are the same for all material). 


\section{RESULTS}

Family Ammodytidae

Bleekeria Günther, 1862

Bleekeria kallolepis Günther, 1862

Proposed new common name: yellow-striped sandlance Figs. 1-5, Table 1

Bleekeria kallolepis Günther, 1862; Günther 1862: p. 387; Pillay 1929: p. 362; (?) Krishnan and Mishra 1993: p. 232; Ida et al. 1994; Joshi et al. 2012;

Ammodytes kallolepis; Day 1878: p. 420, pl. XCI, fig. 3; Ammodytes callolepis; Day 1889: p. 437, fig. 154.

Holotype. British Museum Natural History, BMNH 1846.11.22, from Chennai (previously Madras).

Diagnosis. Dorsal fin rays 40; pectoral fin rays 13-14; pelvic fin absent; anal fin rays 15-16; lateral line 98-105, gill rakers $6+1+19-20=26-27$; branchiostegal rays 7 . Body depth at dorsal origin $11.1 \%-11.8 \% \mathrm{SL}$; head length 4.6-4.8 in SL; eyes large, eye diameter $3.35 \%-4.4 \%$ SL. Body with 3-4 broken, discontinuous yellow stripes.

Description. Small fish (maximum size $150 \mathrm{~mm}$ TL) with elongate cylindrical body, single long dorsal fin, all dorsal and anal rays segmented, and all but last eight dorsal rays branched; pectoral-fin rays 13-14, upper and lower 2-3 rays unbranched; pectoral axillary scale well developed; anal fin rays 15-16; lateral-line scales 98-105; head naked; scales on body thin and weakly ctenoid; scales rows above lateral-line 3-4/17-19; branchiostegal rays 6; body depth at dorsal-fin origin $11.05 \%-11.8 \% \mathrm{SL}, 8.4-9.0$ in SL; body elongate and subcylindrical, width at dorsalfin origin 1.4-1.5 in body depth at dorsal origin, becoming progressively more compressed posteriorly; head length 4.6-4.8 in SL, snout length 3.7-4.0 in HL; mouth large, terminal; lower jaw strongly projecting, lower jaw protruding $8.6 \%-9.1 \% \mathrm{HL}$ before front of snout, triangular in dorsal view, mouth moderately large, minute teeth present in jaws, upper-jaw length 3.5-3.6 in HL, and oblique, forming an angle of about $30^{\circ}$ to horizontal axis of body; gill opening broad, gill rakers long, eye large, 5-6 in HL; interorbital width $5.0-5.7$ in HL; caudalpeduncle depth 3.0-3.4 in HL; caudal-peduncle length 7.3-8.0 in SL. predorsal length 4.2-4.5 in SL; first dorsal ray 9.4 in $\mathrm{HL} ; 16$ th to 20 th dorsal rays longest, 1.9-2.9 in HL; preanal length 1.5-1.6 in SL; anal fin half length of dorsal, caudal fin shallowly forked, caudal fin length 5.9-7 in SL; pectoral fins below level of ventral edge of orbit, middle rays longest, 1.6-1.8 in HL.

Distribution: Western Bay of Bengal to south-west coast of India. Reported from Visakhapatnam (earlier also known as Waltair), Chennai (Madras), Tuticorin (Bineesh K.K, pers. comm. and image) and Trivandrum (Gunther 1862, Day 1878, Pillay 1929). Ida et al. (1994) also mentioned a sandlance species, identified as Bleekeria kallolepis, from the Andaman Sea. However, this distribution record needs to be confirmed, as there is a possibility of misidentification with other similar species. Colour. Generally light bluish or light bluish green background in the upper part of body; pale or pinkish ventrally. Three or four thin broken/irregular bright to golden yellow stripes on body (stripes clearest mostly in anterior dorsal region, fading towards caudal region); of these, three yellow stripes below lateral line, stripe just below lateral line slightly wider, stripe on lateral line extending to upper caudal peduncle (Fig. 1); lateral line stripe, forming a partial ' $\mathrm{X}$ ' cross in the caudal peduncle region with lower stripes. Upper portion of dorsal fin membranes yellowish, basal region fin membrane pale. Opercular region with a clear yellow spot, laterally in line with eye. Posterior margin of the caudal fin with a thin black border.

Colour after preservation. Dorsal half of body olive brown, scales narrowly edged in blackish, lateral line clearly pale; 3-4 pale/light yellow stripes visible in upper part of body. Ventral half of body pale/yellowish (Fig. 2).

\section{REMARKS AND DISCUSSION}

Bleekeria kallolepis, locally called "aruna" (in Tamil), are regularly caught by trawlers operating within $80 \mathrm{~m}$ (mostly within $40 \mathrm{~m}$ ) depth along the east coast of India and locally marketed for domestic consumption (Rajapackiam and Mohan 2012). After the original description, species name was rarely used in the scientific literature. Ida et al. (1994) mentioned a $103 \mathrm{~mm}$ SL specimen in the BMNH from Madras as the holotype and Fricke et al. (2018) provided holotype details of BMNH 1846.11.22 (Fig. 3-4), other B. kallolepis material mentioned in Ida et al. (1994) came from Torutua National Park, Andaman Sea, Thailand, which needs verification.

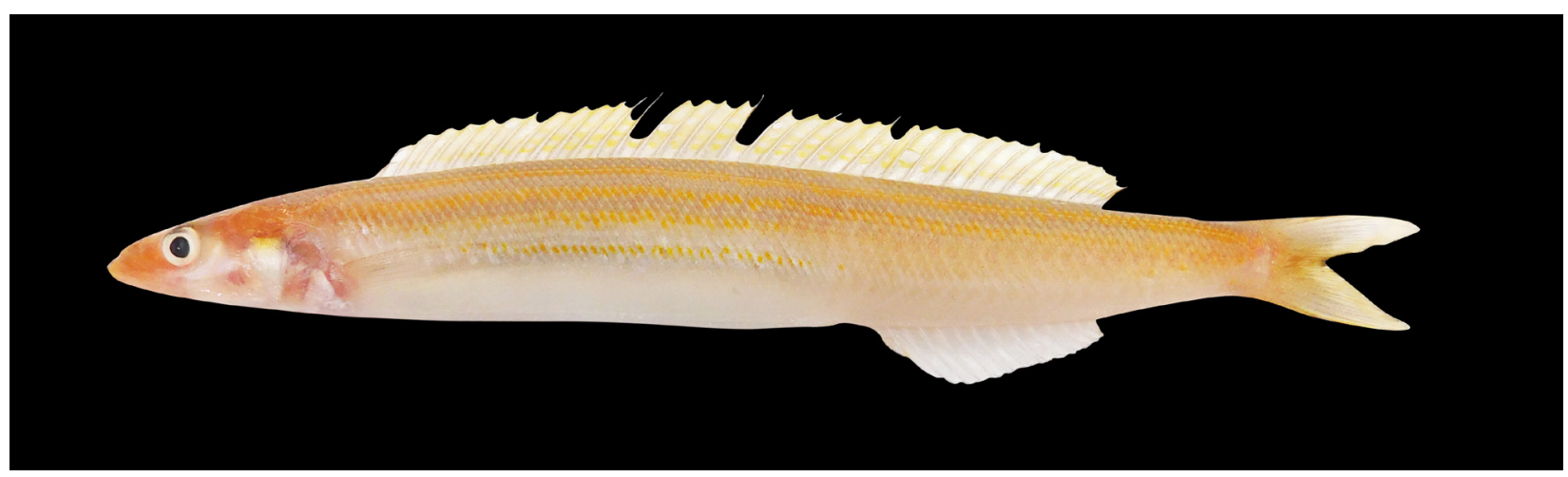

Fig. 1. Lateral image (freshly caught) of Bleekeria kallolepis (BNHS MF 17, 140.1 mm TL 
Table 1

Measurements of Bleekeria kallolepis from Chennai, eastern Indian Ocean (measurements expressed in \%SL) and compared with Bleekeria murtii from Joshi et al. (2012)

\begin{tabular}{|c|c|c|c|c|c|}
\hline & Bleekeria kallolepis & Bleekeria kallolepis & Bleekeria kallolepis & Bleekeria kallolepis & Bleekeria murtii \\
\hline & BNHS MF 16 & BNHS MF 17 & CMFRI M BK3 & CMFRI M BK4 & CMFRI GB.5.1.1 \\
\hline Total length [mm] & 138.4 & 140.1 & 139.6 & 127.6 & 144.6 \\
\hline Standard length $[\mathrm{mm}]$ & 120.3 & 121.4 & 122.1 & 110.4 & 126.5 \\
\hline Fork length $[\mathrm{mm}]$ & 126.5 & 129.1 & 130.2 & 118.0 & 135.0 \\
\hline Body depth (D origin) & 11.8 & 11.8 & 11.1 & 11.3 & - \\
\hline Body width (D origin) & 7.8 & 8.1 & 7.9 & 8.2 & - \\
\hline Body depth (A origin) & 11.7 & 12.7 & 11.5 & 11.9 & - \\
\hline Body width (A origin) & 8.8 & 8.4 & 8.5 & 8.1 & - \\
\hline Greatest body width & 9.1 & 8.9 & 9.0 & 9.1 & 6.2 \\
\hline Greatest body depth & 12.1 & 12.9 & 12.5 & 12.8 & 13.0 \\
\hline Head length & 20.9 & 21.4 & 21.2 & 21.9 & 21.1 \\
\hline Head width at gill & 7.9 & 7.5 & 7.9 & 8.0 & 8.2 \\
\hline Snout length (pre orbit) & 5.7 & 5.3 & 5.4 & 5.5 & 7.0 \\
\hline Orbit diameter & 3.5 & 4.0 & 4.0 & 4.4 & 3.7 \\
\hline Interorbital width & 3.6 & 4.3 & 4.2 & 3.9 & 3.6 \\
\hline Post orbital length & 12.0 & 11.9 & 11.9 & 12.2 & 11.0 \\
\hline Upper jaw length & 5.8 & 5.9 & 6.1 & 6.0 & 2.9 \\
\hline Lower jaw length & 6.4 & 6.3 & 6.8 & 6.8 & 3.5 \\
\hline Caudal peduncle depth & 7.0 & 6.7 & 6.5 & 6.3 & 6.7 \\
\hline Caudal peduncle length(lower) & 12.6 & 13.5 & 13.7 & 13.2 & 11.8 \\
\hline Caudal peduncle width & 4.6 & 4.2 & 3.9 & 3.6 & - \\
\hline Predorsal length & 23.8 & 22.2 & 23.3 & 23.6 & 21.6 \\
\hline Preanal fin length & 63.9 & 64.2 & 64.0 & 64.9 & 64.0 \\
\hline Dorsal fin length & 65.5 & 64.4 & 61.8 & 63.3 & - \\
\hline Dorsal height & 10.8 & 8.0 & 8.0 & 7.3 & 6.6 \\
\hline Dorsal fin base length & 62.1 & 61.5 & 60.2 & 60.1 & 59.8 \\
\hline First dorsal ray length & - & 2.3 & - & - & - \\
\hline Second dorsal ray length & - & 4.0 & 4.7 & - & - \\
\hline Longest dorsal ray length & 11.1 & 7.9 & 7.6 & 7.6 & - \\
\hline Anal fin length & 21.3 & 21.8 & 22.2 & 22.6 & - \\
\hline Anal fin base & 18.3 & 20.3 & 19.3 & 19.8 & 19.8 \\
\hline First anal ray length & 5.3 & 4.0 & 3.9 & 5.7 & - \\
\hline Second anal ray length & 6.0 & - & 7.0 & 7.0 & - \\
\hline Longest anal ray & 6.8 & 7.4 & 7.5 & 7.1 & - \\
\hline Last anal ray length & 3.0 & 2.8 & 3.1 & 2.9 & - \\
\hline Caudal fin length & 15.3 & 17.1 & 14.3 & 16.3 & 12.6 \\
\hline Pectoral fin length & 12.6 & 12.1 & 11.8 & 13.4 & 8.9 \\
\hline Pectoral fin base length & 2.9 & 2.8 & 2.8 & 3.2 & 2.9 \\
\hline
\end{tabular}

The characters and colour description of Bleekeria type material or collect additional material of B. murtii murtii provided in Joshi et al. (2012; table 5) match well from Tuticorin (type locality of B. murtii) to ascertain B. kallolepis of the presently reported study from its the status of this species. The general colour pattern of type locality, except for few morphometrics (e.g., jaw currently examined B. kallolepis specimens well fit length). However, the authors were unable to examine the with the drawing, description, and counts of Günther 
(1862), Day (1878, 1889, Fig. 5), and Ida et al. (2004). fishes from region (Collette 2001, Ida et al. 2004) in their Hora and Mukerji (1934) reported another ammodytid colour pattern and several morphometrics including eye fish, Ammodytes lanceolatus Le Sauvage, 1824 from diameter, dorsal and anal base lengths, etc. (AKV pers. Maungmagan, Myanmar (previously Burma) which needs obs.). A detailed study of ammodytid fishes in the Indian to be verified since A. lanceolatus (currently Hyperoplus Ocean region could reveal more diversity and clarify the lanceolatus) is an Atlantic Ocean species. Moreover, status of the species of sandlance reported from the region. during the surveys of R/V Dr. Fridtjof Nansen in the Myanmar waters in 2018 (2018411), ammodytid fishes of genus Bleekeria were collected at station 79 at $115 \mathrm{~m}$ depth and appear to be different from known Bleekeria

\section{ACKNOWLEDGEMENTS}

Scientist-in-Charge, Chennai RC, CMFRI is acknowledged for the facilities extended. The EAF-Nansen

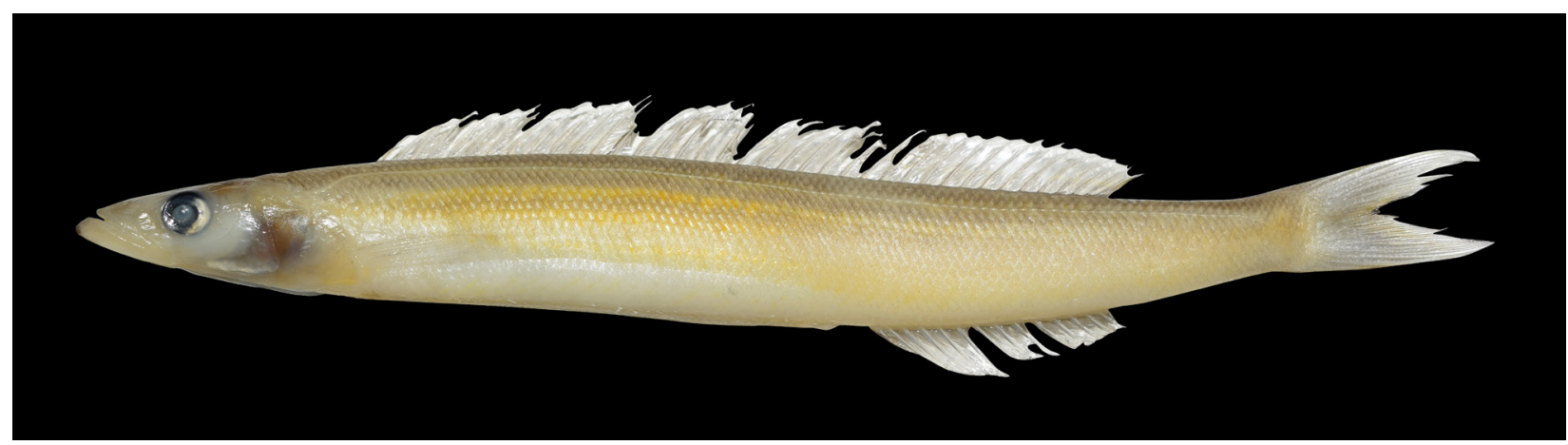

Fig. 2. Lateral image (formalin preserved) of Bleekeria kallolepis (BNHS MF 17, 140.1 mm TL)

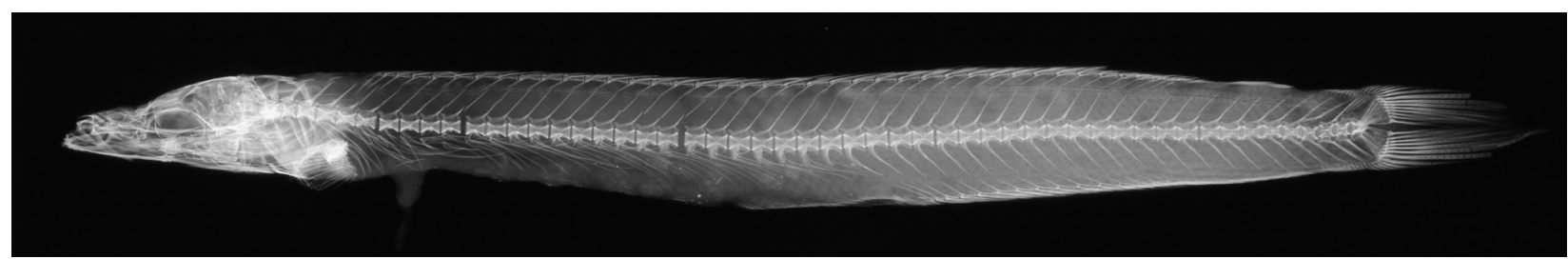

Fig. 3. X ray of Holotype of Bleekeria kallolepis (103 mm SL, BMNH 1846.11.22 Anonymous 2014)

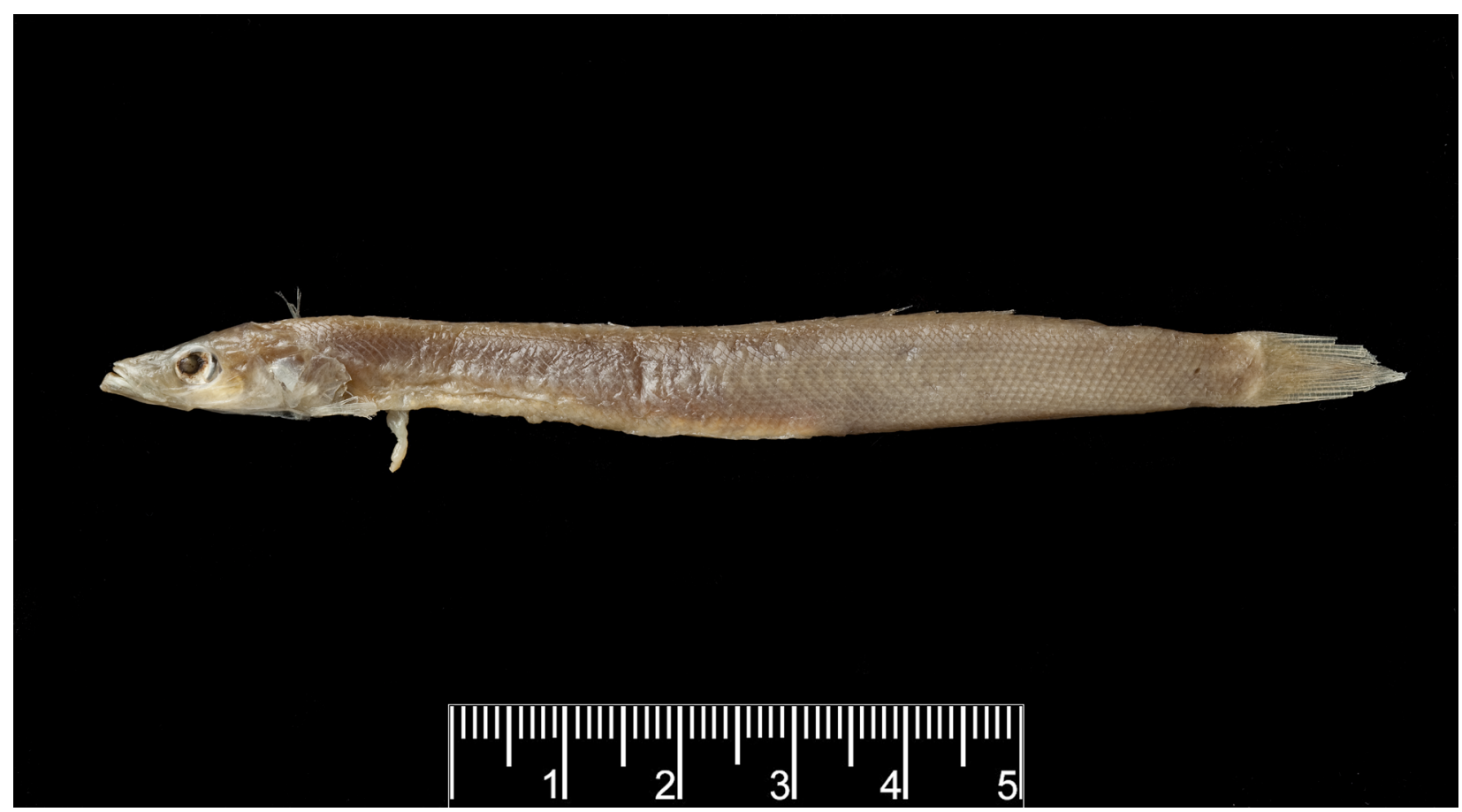

Fig. 4. Holotype of Bleekeria kallolepis (103 mm SL, BMNH 1846.11.22 Anonymous 2014) 


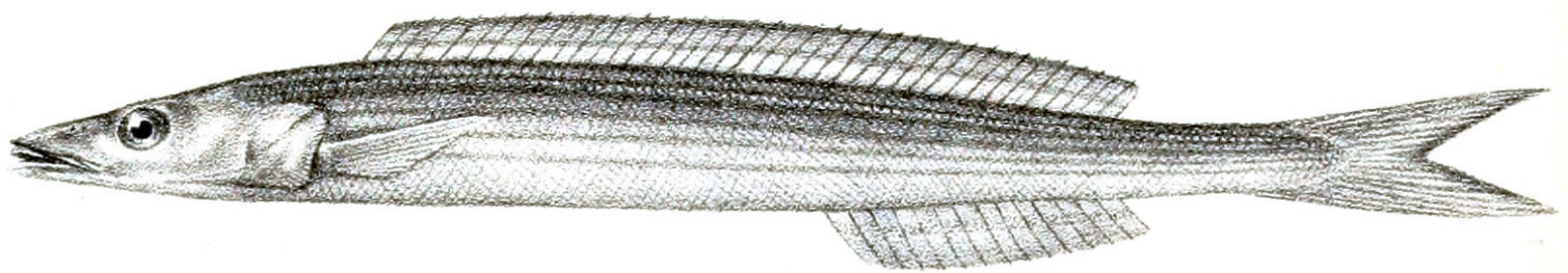

Fig. 5. Image of Bleekeria kallolepis from Day (1889, fig. 154)

Programme by the FAO in collaboration provided AKV the opportunity to examine specimens collected during the R/V Dr. Fridtjof Nansen surveys in Myanmar 2018, which is acknowledged. Thanks to The Bombay Natural History Society (BNHS), Bombay for the museum accession number. Support by Sajeela N (CMFRI, Kochi) in a barcoding study is much appreciated. Thanks to Bineesh for sharing information and images from Tuticorin.

\section{REFERENCES}

Anonymous 2014. Dataset: Collection specimens. Specimen records from the Natural History Museum's collection. Resource: Specimens. Natural History Museum Data Portal. [Retrieved: 16:45 09 Apr 2018 (GMT)] DOI: 10.5519/0002965

Collette B.B. 2001. Family Ammodytidae. P. 3518. In: Carpenter K.E., Niem V.H. (eds.) Species identification guide for fishery purposes. The living marine resources of the western central Pacific. Bony fishes part 4 (Labridae to Latimeriidae), estuarine crocodiles, sea turtles, sea snakes and marine mammals. FAO, Rome.

Day F. 1878. The fishes of India; being a natural history of the fishes known to inhabit the seas and fresh waters of India, Burma, and Ceylon. Volume I, text. Volume II. Atlas-Containing 198 plates, Bernard Quaritch, London, England. DOI: 10.5962/bhl.title.62705

Day F. 1889. Fishes.-Vol. II. In: Blanford W.T. (ed.) The fauna of British India, including Ceylon and Burma. Taylor and Francis, London, England. DOI: 10.5962/ bhl.title. 100755

Fricke R., Eschmeyer W.N., van der Laan R. (eds.) 2018. Catalog of fishes: Genera, species, references. California Academy of Sciences, San Francisco, USA. [Accessed on 14 September 2018.] http://researcharchive.calacademy.org/research/ ichthyology/catalog/fishcatmain.asp

Günther A. 1862. Catalogue of the fishes in the British Museum. Volume Fourth. Catalogue of the Acanthopterygii, Pharyngognathi and Anacanthini in the collection of the British Museum. British Museum, London, England. DOI: 10.5962/bhl.title.8304

Hora S.L., Mukerji D.D. 1936. Notes on fishes in the Indian Museum. XXVII. On two collections of fish from Maungmagan, Tavoy District, Lower Burma. Records of Indian Museum, Calcutta 38 (1): 15-39.
Harwood J., Croxall J.P. 1988. The assessment of competition between seals and commercial fisheries in the North Sea and the Antarctic. Marine Mammal Science 4 (1): 13-33. DOI: 10.1111/j.1748-7692.1988. tb00179.x

Ida H., Sirimontaporn P., Monkolprasit S. 1994. Comparative morphology of the fishes of the family Ammodytidae, with a description of two new genera and two new species. Zoological Studies 33 (4): 251277.

Joshi K.K., Zacharia P.U., Kanthan P. 2012. Description of a new sand lance species, Bleekeria murtii (Perciformes: Ammodytidae) from India. Indian Journal of Fisheries 59 (2): 101-107.

Krishnan S., Mishra S.S. 1993. On a collection of fish from Kakinada-Gopalpur sector of the east coast of India. Records of the Zoological Survey of India 93: 201-240.

Pillay R.S.N. 1929. A list of fishes taken in Travancore from 1901-1915. Journal of the Bombay Natural History Society 33 (2): 347-379.

Rajapackiam S., Mohan S. 2012. Unusual landing of sand eel Bleekeria sp. at Chennai. Marine Fisheries Information Service; Technical and Extension Series (212): 19.

Randall J.E., Ida H. 2014. Three new species of sand lances (Perciformes: Ammodytidae) from the southwest Indian Ocean. Journal of the Ocean Science Foundation 12: 1-11. DOI: 10.5281/zenodo.1049125

Wanless S., Daunt F., Camphuysen C.J., Humphreys E., Scott B., Hamer K.C. 2005. Setting the scene: Colony based and at-sea data on seabirds. Pp. 88134. In: Camphuysen C.J. (ed.) Final report to EU, 'Interactions between the Marine environment, Predators, and prey: implications for sustainable sandeel fisheries (IMPRESS). Texel, The Netherlands.

Wanless S., Harris M.P., Greenstreet S.P.R. 1998. Summer sandeel consumption by seabirds breeding in the Firth of Forth, south-east Scotland. ICES Journal of Marine Science 55 (6): 1141-1151. DOI: 10.1006/ jmsc. 1998.0372

Received: 1 May 2018 Accepted: 7 October 2018 Published electronically: 15 March 2019 